\title{
Varicose Veins: Prevalence and Associated Risk Factors among Women of Childbearing Age Attending a Primary Health Care Unit in Cairo, Egypt
}

\author{
Saher G. Aly ${ }^{1}$, Maha M. Wahdan ${ }^{2 *}$, Dina H. Ahmed ${ }^{3}$, Emad -Eldin F. Ibrahim ${ }^{3}$, Diaa M. Abd El- \\ Hamid $^{4}$ \\ ${ }^{1}$ Ministry of Health, Cairo Governorate, Saraya El-Qobba Primary Healthcare Center, ${ }^{2}$ Department of \\ Community, Environmental and Occupational Medicine, ${ }^{3}$ General Surgery Department, ${ }^{4}$ Family Medicine \\ Department, Faculty of Medicine, Ain Shams University, Egypt
}

\begin{abstract}
:
Background: Varicose veins are very common and affect individuals of all ages; however, unfortunately, their aetiology is partially understood. There is a scarcity of studies in Egypt investigating their prevalence and associated risk factors, especially among women of childbearing age. Objectives: This study was conducted to measure the prevalence and identify the risk factors associated with varicose veins among women of childbearing age (15-55 years old) attending primary healthcare center in Cairo. Methods: A cross-sectional study was conducted on 231 women attending El-Nahda center in the El-Salam medical area in Cairo, selected by systematic random sampling technique. Data were collected using an interview questionnaire and clinical examination. Results: the study shows that among 231 women of childbearing age (15-55 years old) attending primary healthcare center in Cairo, $(51.1 \%)$ had varicose veins, and the most significant associated risk factors were age $(35.84 \pm 9.14$ years $)$, weight $(78.13 \pm 13.62 \mathrm{~kg})$, duration of standing during a working day (7.72 \pm 2.54 days), hypertension (72\%), lack of physical activity (56.9\%), and family history of varicosities (45.5\%). Conclusion: There was a high prevalence of leg varicose veins among the participants, and the risk of varicose veins increases with increasing age, prolonged standing, hypertension, having family history of varicosities and the absence of regular physical exercise. Recommendations: Health education programs should aim at controlling preventable risk factors for varicose veins, and screening for women with a family history of varicose veins should be strengthened.
\end{abstract}

Keywords: Prevalence, Risk Factors, Varicose Veins, Women.

\section{Introduction:}

The venous system is a vital part of the circulatory network owing to its ability to constrict and dilate, store large volumes of blood for use in other areas, and even regulate cardiac output. ${ }^{(1)}$

Varicose veins are abnormally swollen, dilated and tortuous sub-cutaneous veins. The American Venous Forum developed a detailed descriptive classification system for chronic venous disorders in 1994, which was published in 25 journals and books. It was based on clinical manifestations (C), aetiological factors (E), the anatomic distribution of disease (A), and underlying pathophysiological findings (P). In 2004, the advanced CEAP classification system was published. $^{(1)}$

The aetiology of varicose veins is still only partially understood; the occurrence of varicose veins may be due to primary venous disease or intrinsic morphologic or biochemical abnormalities in the venous wall. Varicosities can also develop as a result of

*Corresponding author: E-mail: drmaha_wahdan@med.asu.edu.eg 
secondary causes, such as previous deep vein thrombosis (DVT), deep venous obstruction, superficial thrombophlebitis, or arterio-venous fistula. Varicose veins may also be congenital and present as venous malformations. ${ }^{(2)}$

The incidence of varicose veins increases with advancing age and is relatively higher in females and those with a family history of varicose veins. Obesity, especially in women, smoking and prolonged standing at work, are considered potential risk factors for varicosities. ${ }^{(3,5)}$

Varicose veins is considered a prevalent disease affecting all age groups from teenagers to elderly people. The occurrence of varicose veins varies worldwide, with reported incidence rates ranging from $20 \%$ to $64 \%$. The highest reported rate is in the Western world. Among women older than 18 years, the prevalence of varicose veins has reached $49.6 \%$ and $47.7 \%$ in Saudi Arabia and Iran, respectively. Among pregnant women, the prevalence of varicose veins varies widely from 20 to $50 \%$, and it may reach $70 \%$ of women if all types of varicose veins are included, such as telangiectasias. Varicose veins occur during pregnancy due to the enlarged gravid uterus and the resulting hypertension and distension in the lower extremity veins and an increase in hormone secretion, which weakens the venous wall. ${ }^{(3,4 \text {, }}$ $6,7,8,9)$

Patients with varicose veins may present with no symptoms except those of cosmetic concern, which have a psychological impact that may reduce the patient's quality of life. Other patients report symptoms related to varicose veins such as tingling, aching, burning, pain, swelling, the sensation of heaviness, restless legs, leg tiredness, and fatigue. $^{(10)}$

Hence, varicose veins are considered a problem with substantial psychological, physical and financial impacts because they affect work efficiency and lead to increases in disability and costs of treatment. Therefore, it is necessary to plan to control the risk factors and prevent complications. This study was conducted with the aim of measuring the prevalence of varicose veins and identifying the associated risk factors among women of childbearing age (15-55 years old) attending a primary healthcare center (PHC) in Cairo.

\section{Material and Methods:}

Study design and setting: A cross-sectional study was conducted among women of childbearing age (15-55 years old), and all women visiting the family health care center 
at El-Nahda in the El-Salam medical area in Cairo for any reason were eligible.

Sampling method: A systematic random sampling technique was performed during two-day visits to the center each week over 9 months. On average, three women were interviewed at each visit.

Sample size: Based on the lowest prevalence of varicose veins in females $(29 \%)$, the highest recorded prevalence $(55 \%)$, the power of study $(80 \%)$, and the alpha error $(5 \%)$, the calculated sample size needed was 200 subjects. The programme used for calculating the sample size was STATA10. Thirty-one additional subjects $(15 \%)$ were enrolled to compensate for any missing or incomplete data.

Data collection tool: Data were collected from the participants via an interview questionnaire (26 questions) and a clinical examination.

(I) The interview questionnaire collected data on the following:

1. Socio-demographic variables (e.g., age, occupation, and education).

2. Symptoms of varicose veins such as the sensation of heaviness in the $\operatorname{leg}(\mathrm{s})$ in the afternoon, pain or a prickling sensation in the leg(s) during the daytime, swelling of the ankle or leg, swelling of the thigh(s), considerable leg pain while standing, numbness in the $\operatorname{leg}(\mathrm{s})$, lower extremity pain while at rest, long-standing ulceration or necrosis of the foot or leg, pain relief upon leg elevation, and the presence of other symptoms.

3. Risk factors such as occupation (hours spent standing or sitting), special habits (smoking, physical exercise "it is defined as any planned physical activity (e.g. brisk walking, aerobics, jogging, bicycling, swimming, rowing, etc.) performed to increase physical fitness. Such activity should be performed 3 to 5 times per week for 20-60 minutes per session" (27) , parity, obesity, family history of varicosity (parents, grandparents or siblings), the use of contraceptive pills including the duration, the use of medications for any disease, any history of chronic diseases, problems with arterial circulation of the leg, any fractures in the lower extremities, any major contusions with prolonged healing in the lower extremities, leg ulcerations, malignant diseases, and past and current medical and surgical histories.

This interview questionnaire was adapted from a cohort study by Makivara et al. The validation of the questionnaire was performed by comparing the results with a surgeon`s 
diagnosis in 166 randomly selected 50-yearold participants in the survey. The results of this validation showed that the accuracy of the questionnaire was relatively high, with a specificity of $0.9(95 \%$ CI $0.8-1.0)$ and a sensitivity of 0.9 (95\% CI $0.8-1.0)$ in women. (26)

The questionnaire was translated to Arabic to be suitable for the Egyptian population, and the back translation was then compared with the original U.S. English version. After translation, the questionnaire was tested on 10 patients to assess the clarity of questions and the time needed to fulfil the questionnaire.

(II) General and local examination of the participants: General and local examinations were conducted, looking for signs of varicosity and, if found, grading it clinically according to the CEAP classification as follows:

Class 0- No visible or palpable signs of venous disease.

Class 1- Telangiectasias or reticular veins.

Class 2- Varicose veins ( $>3 \mathrm{~mm}$ in diameter). Class 3- Oedema.

Class 4a- Pigmentation or eczema.

Class 4b- Lipodermatosclerosis (inflammation of the layer of fat under the epidermis).
Class 5- Healed venous ulcer.

Class 6- Active venous ulcer.

\section{Data management and analysis:}

Data were revised, coded, entered into a personal computer and analysed using SPSS package version number 20. Quantitative data are described as the mean and standard deviation (SD). Independent t-tests were used to compare quantitative variables between groups, and p-values $\leq 0.05$ were considered significant. Qualitative data are expressed as frequencies (n) and percentages (\%). Chisquare tests were used to determine the association between qualitative variables, and a $p$-value $\leq 0.05$ was considered significant. Multivariate logistic regression was performed to identify independent predictors of varicose veins. Significant variables in univariate analysis were introduced to develop a statistical model for the occurrence of varicosity using the enter model. A P-value $\leq$ 0.05 was considered significant.

\section{Ethical considerations:}

The research ethics committee (REC) of the Faculty of Medicine at Ain Shams University approved this study. Administrative approval from the director of the primary health care unit was obtained. Informed consent was obtained from each woman after discussing 
the purpose and benefit of the study. The confidentiality of the data was maintained through anonymity, and the confidentiality of the results was assured.

\section{Results:}

Socio-demographic characteristics:

The 231 participants had a mean age of 34.6 years, the majority had completed a university-level education (55.4\%), and half were house wives $(50.2 \%)$. More than twofifths of the participants $(43.3 \%)$ were overweight (Body mass index (BMI) 2529.9).

Seventy-two percent (72\%) of the studied women had given birth, $26.8 \%$ of the patients had a history of using contraceptive pills and $12.6 \%$ had worn corsets. In total, $90 \%$ worked while standing and 10\% moved during work.

Among the participants, $71.4 \%$ had a sedentary lifestyle, and walking was the only type of exercise practised by $72.7 \%$ of those who engaged in exercise $(28.6 \%$ of all participants). Regarding the duration of physical exercise per day, the mean value was 42.9 minutes per day, 3.3 times per week.

Prevalence and characteristics of varicose veins: Approximately $51.1 \%$ of the participants had varicose veins. Regarding the signs and symptoms of varicose veins, cosmetic issues were the main complaint for $61.9 \%$ of the affected patients. Forty-eight percent experienced a sensation of heaviness in the legs, $46.3 \%$ had pain or a prickling sensation, and $29 \%$ had swelling of the ankles or legs. Additionally, considerable leg pain while standing was present in $62.3 \%$ of the investigated women, and pain in the lower extremities at rest was evident in $26 \%$ of the studied women. A total of $16.9 \%$ of the patients had permanent changes in the colour of the skin on the ankle. A total of $1.3 \%$ of the patients complained of long-standing ulceration of the leg (Table 1). The 12 classes of different effects of varicose veins were noticed in our patients, in whom $\mathrm{C} 1$ (telangiectasia, 36.8\%) was the most common class (Table 2).

Symptoms were relieved by leg elevation in $74.5 \%$ of the participants. Among the 118 patients with varicose veins, $30.5 \%$ were treated with compressive stockings for more than one month. Only $2.5 \%$ of patients underwent a surgical operation, while 8.5\% were treated with sclerotherapy (injections in the varicose veins). Varicosities reappeared after treatment in $61.5 \%$ of patients who received different types of treatment, and $56.8 \%$ needed treatment during the time of the study (Table 3). 
Risk factors associated with varicose veins:

Univariate analysis showed that occupation, education, age, weight, family history of varicose veins, lack of exercise, high blood pressure, long standing duration, and shorter exercise duration were significantly associated with the occurrence of varicose veins (Tables 4 \& 5). Logistic regression showed that occupation, duration of standing during the working day, practising physical exercise, and a family history of varicose veins are independent predictors of the occurrence of varicose veins $(p<0.05)$ (Table 6).

\section{Discussion:}

The prevalence of varicose veins among the women surveyed and examined in this study was $51.1 \%$. This finding was similar to that found in a cross-sectional study performed among 197 female hairdressers working in Shahroud, Iran, in whom the prevalence of varicose veins was $47.7 \%$. (9) These results might be due to the common significant risk factors present in both studies, such as advancing age, family history, and duration of standing and presence of hypertension. In contrast, the prevalence in the present study was higher than that in a study performed with nurses working at a university hospital in Pusan, republic of Korea, in which $16.5 \%$ of the women suffered Egyptian Family Medicine Journal (EFMJ) from varicose veins. (11) However, a much higher prevalence $(78 \%)$ of varicose veins was found in another study among female nurses in the general hospital in Amol, Iran. (12)

Our results regarding the site of varicose veins revealed that both legs were affected in $22.9 \%$ of the women, which differed from the results of a previous study performed by Joseph et al. in a hospital in Mangalore, a coastal city in southern India, in which the most common site was on the left side $(34.1 \%)$. (13) Bilateral presentation of varicose veins was observed in $20 \%$ of the cases investigated by Das et al. in Liaquat University Hospital in Hyderabad, Pakistan and was observed in $37.1 \%$ of the cases in the study by Joseph. $(13,14)$ These results could be due to the women spending eight or more hours on an average day in sedentary activities (sitting or standing) and the reduced level of daily physical activity as were found in our study and the others.

\section{Regarding the signs and symptoms} of varicose veins, the main problem was cosmetic appearance $(61.9 \%)$, the sensation of heaviness in the $\operatorname{leg}(\mathrm{s})(48.9 \%)$, and considerable leg pain while standing (62.3\%). Pain in the lower extremity at rest was reported in $26 \%$ of the studied women, while 
only $1.3 \%$ of the patients complained of longstanding ulcerations of the leg. As in the present study, other studies found that the main manifestations of varicose veins of the lower extremity in female nurses in east China were protrusion of the venules of the lower limb affecting the aesthetic appearance of the leg (cosmetic problem) and negatively impacting their mental health and swollen legs. ${ }^{(15,16,17)}$ In a study by Joseph et al., pain was the second most frequent complaint reported in $56.5 \%$ of cases ${ }^{(13)}$, and oedema of the limbs was reported in $20 \%$ of cases, whereas oedema was reported in $42.5 \%$ of cases of varicose veins in the Robertson study conducted in Edinburgh in the United Kingdom, which is considered a very high percentage. $(13,15)$ In contrast to our findings, the most common presenting symptom of varicose veins was ulceration in the Joseph et al. study and venous pain and heaviness in the Zolotukhin et al. study. ${ }^{(13,20)}$ Other studies found eczema, skin trophic changes and lipodermatosclerosis, and these skin conditions are usually complications due to late diagnosis of chronic venous insufficiency and ulceration, making a cure difficult. $(15,18$, 19) As a result of these findings, it is important to discover varicose veins early before complications occur; therefore, screening and clinical examinations of females of childbearing age should be performed on a regular basis to detect and treat varicose veins early.

With regard to the relieving methods and treatment, most of the participants who had varicose veins reported that their symptoms were relieved by elevating their $\operatorname{leg}(\mathrm{s})(74.5 \%)$. Varicosities reappeared after treatment in $61.5 \%$ of the 39 patients who received different types of treatment. Approximately $30.5 \%$ of patients affected with varicose veins in the present study were treated by compressive stockings for more than one month, while $8.5 \%$ were treated with sclerotherapy (injections in varicose veins), and only $2.5 \%$ of patients underwent surgical operations. Our findings were consistent with the findings of Yun et al. in Korea, who used compression stockings for prevention and treatment purposes ${ }^{(11)}$, while the Klitfod study reported that $31 \%$ of patients were treated with open surgery, which is different from the current results. This difference may be attributed to the nature of the Klitfod study, as it assessed the effects of different treatment methods on relieving the symptoms of patients with varicose veins. ${ }^{(21)}$

Regarding the risk factors associated with varicose veins, the current Vol .4(1), May. 2020 www.efmj-eg.org 
study found that the mean age of patients with varicose veins was 35.8 years, and there was a significant association between age and the presence of varicose veins. These findings were similar to the results of other studies, in which increasing age was associated with a greater chance of developing varicose veins. $(9,11,12,20,22,23)$ Additionally, there was a significant difference in the prevalence of varicose veins among women with different levels of occupation and education, with a higher prevalence of varicose veins noted among workers (labourers) (76.9\%) and illiterate women (94.4\%) than among nonworkers and educated women. This finding may be due to the fact that workers are exposed to long period of standing, which is considered a risk factor. ${ }^{(9,15,20)}$

Our finding that parity is not significantly associated with the occurrence of varicose veins conflicts with the results of previous studies that found pregnancy to be a significant risk factor that remained significant after adjusting for age. $(9,15,20)$

A family history of varicose veins was significantly associated with the occurrence of varicosities, as was clear from the high percentage of participants who had a family history of varicosities (72.4\%) compared with those who did not $(33.3 \%)$. This finding is consistent with those of previous studies showing that family history is a risk factor for varicose veins. $(9,24,25)$

Regarding the anthropometric measurements, weight was significantly associated with the occurrence of varicosities, but there was no significant association between any BMI subgroups and the occurrence of varicose veins $(p=0.185)$. In concordance with our results, multiple studies found that obesity and weight gain are risk factors for varicose veins. ${ }^{(9,22,23)}$ On the other hand, overweight was not found to be a significant risk factor, while elevated BMI was identified as a risk factor for varicosity in other studies. $(24,25)$

Our results regarding posture and duration of standing showed that the posture maintained during work was not significantly associated with the occurrence of varicosities, although the duration of standing in general was. We compared our findings with those of previous studies, and found that prolonged sitting or standing plays an important role not only in the development of varicose veins but also in the pathogenesis of venous symptom owing to the physiology of the venous system. $(11,12,22,25)$ 
Engaging in physical exercise was significantly associated with a reduction in the risk of varicose veins; a similar finding was noted by previous studies, in which the lack of exercise and the performance of unskilled work were identified as significant risk factors. ${ }^{(16,24)}$

Regarding the comorbidities associated with the occurrence of varicose veins, the present study found a statistically significant relationship between varicose veins and hypertension $(\mathrm{p}=0.002)$, a history of a major contusion with prolonged healing in the lower limb $(\mathrm{p}=0.021)$ and a fracture in the lower extremities $(p=0.007)$, while no significant associations were found with other comorbidities. These findings were in agreement with those reported by Ebrahimi et al. in a study conducted in north eastern Iran in which hypertension was significantly associated with varicosity. ${ }^{(9)}$

Multiple logistic regression analysis was performed to find the independent risk factors for varicose veins among females of childbearing age, and only a family history of varicose veins and the duration of daily exercise were independent predictors of the occurrence of varicose veins $(\mathrm{P}<0.05)$. Similar to our findings, Ebrahimi et al. reported that age, blood pressure, family history and standing duration were significantly associated with the occurrence of varicose veins. ${ }^{(9)}$

\section{Study Limitations:}

The use of a cross-sectional design limited the ability to explore the precise strength of the associations between the identified risk factors and the occurrence of varicose veins.

\section{Conclusion:}

The prevalence of varicose veins was relatively high $(51.1 \%)$ among the studied population. The most significant risk factors were increasing age, low educational level, high weight, long duration of standing during a working day, shorter duration of daily exercise, hypertension, a history of major contusion with prolonged healing, having a fracture in the lower extremities, and a family history of having varicosities. After controlling for age, logistic regression revealed that the duration of exercise and family history are independent predictors of varicose veins.

\section{Recommendations:}

Community-based health educational campaigns and training sessions for physicians should be held to increase their awareness about varicose vein symptoms, 
signs, risk factors, and methods of prevention, screening and treatment.

\section{Conflict of interest:}

The authors state that they have no competing interests.

\section{Data Availability Statement:}

The datasets generated and analysed during the current study are available from the corresponding author on request.

\section{Funding:}

There has been no significant financial support for this work that could have influenced its outcome.

\section{Acknowledgement:}

Authors would like to express their great appreciation for the participants who generously shared their time and agreed to participate in this study.

\section{References:}

1. Jindal R, Wadhawan B, Chaudhary P. Anatomy, physiology \& classification of varicose veins. Venous disorders textbook. Chapter 188. Page 867 -869.

2. Bhatti AM, Siddique K, Bashir RA, Sajid MT, Mustafa QA, Hussain SM, et al. Unusual causes of secondary varicose veins. J Ayub Med Coll Abbottabad. 2013; 25: 3-4. Available at:
http://www.ayubmed.edu.pk/JAMC/253/Bhatti.pdf81

3. Robertson L, Evans C, Fowkes FG. Epidemiology of chronic venous disease. Phlebology. 2008; 23: 103-111.

4. Kroeger K, Ose C, Rudofsky G, Roesener J, Hirche H. Risk factors for varicose veins. Int Angiol. 2004; 23: 29-34.

5. Lee AJ, Evans CJ, Allan PL, Ruckley CV, Fowkes FG. Lifestyle factors and the risk of varicose veins: Edinburgh Vein Study. J Clin Epidemiology. 2003; 56:171-179.

6. Junior NB, Perez MD, Amorim JE, Junior FM. Pregnancy and lower limb varicose veins: prevalence and risk factor. J. vasc. Bras. 2010; 9 (2). Available at: http://dx.doi.org/10.1590/S1677-

\section{$\underline{54492010000200004}$}

7. Radak D, Tanaskovic S. Prevention and treatment of venous disorders during pregnancy and the postpartum period. Phlebolymphology. 2017; Vol 24. No. 3. Available at:

https://www.phlebolymphology.org/wpcontent/uploads/2017/12/Phlebolympholog y93.pdf

8. Bawakid KO, Al-Raddadi RM, Sabban SS, Alturky KA, Mohamed MS. Prevalence of chronic venous insufficiency in the Saudi adult population. Saudi Med J. 2005; 26(2):225-229. 
9. Ebrahimi H, Amanpour F, Haghighi BN. Prevalence and risk factors of varicose veins among female hairdressers: A cross sectional study in North- east of Iran. JRHS. 2015; 15(2):119-123.

10. Langer RD, Ho E, Denenberg JO, Fronek A, Allison $\mathrm{M}$, Criqui $\mathrm{MH}$, et al. Relationships between symptoms and venous disease: the San Diego population study. Arch Intern Med. 2005; 165:1420-4.

11. Yun MJ, Kim YK, Kang KM, Kim JE, Ha WC, Jung KY, et al. A Study on prevalence and risk factors for varicose veins in nurses at a university hospital. Safety and Health at Work. 2018; 9 (1):7983.

12. Sharifinia S, Ghorbani M, Beheshti Z, Tayebi S, Mahboubi M, Mirzajani F, Kolbadinezhad M. Determine the prevalence of varicose in lower extremities in nurses and some related factors. Iranian Journal of Nursing Research. 2010; 5 (17): 23-31.

13. Joseph N, Abhishai B, Thouseef MF, Devi U, Abna A, Juneja I. A multicenter review of epidemiology and management of varicose veins for national guidance. Ann Med Surg. 2016; 8: 21-27.

14. Das K, Ahmed S, Abro S, Arain MS. Varicose veins; Outcome of surgical management and recurrences. Professional Medical Journal. 2014; 21(3).

15. Robertson L, Lee AJ, Gallagher K, Carmichael SJ, Evans CJ, McKinstry BH, Ruckley CV. Risk factors for chronic ulceration in patients with varicose veins: a case control study. Journal of Vascular Surgery. 2009; 49(6): 1490-1498.

16. Erding L, Shuyan C, Weiwei Z, Ying Y. Influencing factors for lower extremity varicose veins in female nurses in East China. Biomedical Research. 2017; 28(20).

17. Mallick R., Lal BK, Daugherty C. Relationship between patient-reported symptoms, limitations in daily activities, and psychological impact in varicose veins. J Vasc Surg Venous Lymphat Disord. 2017; 5(2), 224-237.

18. Murli N, Navin I. Classical varicose vein surgery in a diverse ethnic community. Med J Malaysia. 2008; 63(3), 193-198.

19. Bilker W, Santanna J, Baumgarten M. Venous leg ulcer: incidence and prevalence in the elderly. J Am Acad Dermatol. 2002; 46: 381-386.

20. Zolotukhin IA, Seliverstov EI, Shevtsov YN, Avakiants IP, Nikishkov AS, Tatarintsev AM, Kirienko AI. Prevalence and risk factors for chronic venous disease in the general Russian population. Eur $\mathrm{J}$ 
Vasc Endovasc Surg. 2017; 54(6): 752758.

21. Klitfod L, Sillesen H, Jensen LP. Patients and physicians agree only partially in symptoms and clinical findings before and after treatment for varicose veins. Phlebology. 2018; 33(2):115-121.

22. Bihari I, Tornoci L, Bihari P. Epidemiological study on varicose veins in Budapest. Phlebology. 2012; 27(2): 77-81.

23. Clark A, Harvey I, Fowkes F. Epidemiology and risk factors for varicose veins among older people: cross-sectional population study in the UK. Phlebology. 2010; 25(5): 236-240.

24. Agarwal V, Agarwal S, Singh A, Nathwani P, Goyal P, Goel S. Prevalence and risk factors of varicose veins, skin trophic changes, and venous symptoms among northern Indian population. Int J Res Med Sci. 2016; 4(5): 1678-1682.

25. Carpentier P, Maricq HR, Biro C, PoncotMakinen C, Franco A. Prevalence, risk factors, and clinical pattern of chronic venous disorders of lower limbs: A population-based study in France. J Vasc Surg. 2005; 40, 650.

26. Mäkivaara LA, Jukkola TM, Sisto T, Luukkaala T, Hakama M and Laurikka JO. Incidence of varicose veins in Finland. Vasa. 2004; 33:159-163.

27. Sharifirad G., Charkazi A., Tashi M., Shahnazi H., Bahador E. Physical Activity and Stages of Change among College Students. Health Promot Perspect. 2011; 1(1): 71-75. Available at: https://www.ncbi.nlm.nih.gov/pmc/articles/ PMC3963613/. 
Table (1): Prevalence and symptoms associated with varicose veins $(\mathrm{N}=118)$.

\begin{tabular}{|l|l|l|}
\hline Variables & No. & \% \\
\hline Varicose veins in lower extremities * & 118 & 51.1 \\
\hline Site of varicose veins: & & \\
\hline Rt Leg \& Lt Leg & 27 & 22.9 \\
\hline Rt Leg & 25 & 21.2 \\
\hline Lt Leg & 22 & 18.6 \\
\hline Rt Shank \& Lt Shank & 18 & 15.3 \\
\hline Rt Thigh & 11 & 9.3 \\
\hline Lt Thigh & 10 & 8.5 \\
\hline Rt Shank & 3 & 2.5 \\
\hline Lt Shank & 2 & 1.7 \\
\hline Sensation of heavy legs & 113 & 48.9 \\
\hline Pain or prickling sensation & 107 & 46.3 \\
\hline Swelling of ankle or legs & 67 & 29.0 \\
\hline Swelling of thighs & 18 & 7.8 \\
\hline Considerable leg pain while standing & 144 & 62.3 \\
\hline Lower extremity pain while at rest & 60 & 26.0 \\
\hline Permanent change in the colour of the skin on the ankle or leg & 39 & 16.9 \\
\hline Long-standing ulceration of the foot or leg & 3 & 1.3 \\
\hline Varicose veins is a cosmetic problem & 73 & 61.9 \\
\hline
\end{tabular}

(*) The total number is 231 , while in all other rows the total number is 118 . 
Table (2): Classification of varicose veins among affected women $(\mathrm{N}=118)$.

\begin{tabular}{|l|l|l|}
\hline Local Examination & No. & \% \\
\hline C0 (no visible or palpable signs of venous disease) & 79 & 34.2 \\
\hline C1 (telangiectasia) & 85 & 36.8 \\
\hline C2 (varicose veins >3 mm in diameter) & 3 & 1.3 \\
\hline C1/C2 (telangiectasia and varicose veins) & 9 & 3.9 \\
\hline C1/C3 (telangiectasia and oedema) & 18 & 7.8 \\
\hline C1/C4a (telangiectasia and pigmentation) & 2 & 0.9 \\
\hline C1/C2/C3 (telangiectasia, VVs and oedema) & 4 & 1.7 \\
\hline C1/C2/C4a (telangiectasia, VVs and pigmentation) & 8 & 3.5 \\
\hline C1/C2/C4a/C5 (telangiectasia, VVs, pigmentation, healed venous ulcer) & 1 & 0.4 \\
\hline C1/C3/C4a (telangiectasia, oedema and pigmentation) & 9 & 3.9 \\
\hline C2/C4a (VVs and pigmentation) & 1 & 0.4 \\
\hline C2/C3/C4a (VVs, oedema and pigmentation) & 2 & 0.9 \\
\hline C1/C2/C3/C4a (telangiectasia, VVs, oedema and pigmentation) & 10 & 4.3 \\
\hline VVs indicate varicose veins & & \\
\hline
\end{tabular}

VVs indicate varicose veins 
Table (3): Methods of symptom relief and treatment for varicose veins $(\mathrm{N}=118)$.

\begin{tabular}{|l|l|l|}
\hline Variables & No. & $\begin{array}{l}\text { of agreed } \\
\text { participants }\end{array}$ \\
\hline Symptoms relieved when leg elevated & 88 & 74.5 \\
\hline Symptoms relieved when legs left hanging & 4 & 3.4 \\
\hline Varicose veins treated before & 39 & 33.1 \\
\hline Varicosities recurred after treatment* & 24 & 61.5 \\
\hline Treatment with compressive stocking for more than one month & 36 & 30.5 \\
\hline Injections for varicose veins & 10 & 8.5 \\
\hline Operation for varicose veins & 3 & 2.5 \\
\hline Varicose veins need treatment currently & 67 & 56.8 \\
\hline
\end{tabular}

(*) The total number is 39 (total treated for varicose veins), while in all other rows, the total number is 118 . 
Table (4): Socio-demographic characteristics and anthropometric measures in relation to varicose veins.

\begin{tabular}{|c|c|c|c|}
\hline \multirow[t]{3}{*}{ Variables } & \multicolumn{2}{|c|}{$\begin{array}{l}\text { Ever had varicose veins in the lower } \\
\text { extremities }\end{array}$} & \multirow[t]{3}{*}{ P-value } \\
\hline & No & Yes & \\
\hline & $\mathbf{N}(\%)$ & $\mathbf{N}(\%)$ & \\
\hline Age (mean \pm SD) & $33.37 \pm 9.46$ & $35.84 \pm 9.14$ & ${ }^{\mathrm{a}} 0.045^{*}$ \\
\hline \multicolumn{4}{|l|}{ Occupation } \\
\hline Worker & $3(23.1)$ & $10(76.9)$ & \multirow[t]{5}{*}{$0.013^{*}$} \\
\hline House wife & $49(42.2)$ & $67(57.8)$ & \\
\hline Student & $7(53.8)$ & $6(46.2)$ & \\
\hline $\begin{array}{l}\text { Professional worker } \\
\text { (Medical/Engineer/Teacher) }\end{array}$ & $27(69.2)$ & $12(30.8)$ & \\
\hline Employee & $27(54)$ & $23(46)$ & \\
\hline \multicolumn{4}{|l|}{ Education } \\
\hline University & $71(55.5)$ & $57(44.5)$ & \multirow[t]{5}{*}{$0.001^{*}$} \\
\hline Diploma & $23(46)$ & $27(54)$ & \\
\hline Secondary & $10(43.5)$ & $13(56.5)$ & \\
\hline Primary & $8(66.7)$ & $4(33.3)$ & \\
\hline Illiterate & $1(5.6)$ & $17(94.4)$ & \\
\hline \multicolumn{4}{|l|}{ Ever given birth } \\
\hline No & $36(57.1 \%)$ & $27(42.9 \%)$ & \multirow[t]{2}{*}{${ }^{\#} 0.126$} \\
\hline Yes & $77(45.8 \%)$ & $91(54.2 \%)$ & \\
\hline No. of births & $2.39 \pm .98$ & $2.48 \pm 1.04$ & ${ }^{\mathrm{a}} 0.549$ \\
\hline Weight (mean \pm SD) & $73.16 \pm 13.72$ & $78.13 \pm 13.62$ & ${ }^{\mathrm{a}} 0.006^{*}$ \\
\hline Height (mean \pm SD) & $161.73 \pm 6.17$ & $161.38 \pm 4.88$ & ${ }^{\mathrm{a}} 0.638$ \\
\hline \multicolumn{4}{|l|}{ BMI } \\
\hline Normal & $26(60.5)$ & $17(39.5)$ & \multirow[t]{5}{*}{0.185} \\
\hline Overweight & $47(47)$ & $53(53)$ & \\
\hline Obesity grade I & $30(51.7)$ & $28(48.3)$ & \\
\hline Obesity grade II & $9(37.5)$ & $15(62.5)$ & \\
\hline Morbid obesity & $1(16.7)$ & $5(83.3)$ & \\
\hline
\end{tabular}

(') P-value from an independent samples t-test; $\left(^{\#}\right)$ from chi-square test; all others are from Fisher's exact test as $(20.0 \%)$ of the cells or more have expected counts less than 5. (*) Statistically significant at $\mathrm{P}<0.05$. 
Table (5): Relationships between varicose vein occurrence and other studied variables.

\begin{tabular}{|c|c|c|c|}
\hline \multirow[t]{3}{*}{ Variables } & \multicolumn{2}{|c|}{$\begin{array}{l}\text { Ever had varicose veins in the } \\
\text { lower extremities }\end{array}$} & \multirow[t]{3}{*}{ P-value } \\
\hline & No & Yes & \\
\hline & $\mathbf{N}(\%)$ & $\mathbf{N}(\%)$ & \\
\hline \multicolumn{4}{|l|}{ Family history of varicose veins } \\
\hline No & $84(66.7)$ & $42(33.3)$ & \multirow[t]{2}{*}{$<0.001^{*}$} \\
\hline Yes & $29(27.6)$ & $76(72.4)$ & \\
\hline \multicolumn{4}{|l|}{ Posture during work } \\
\hline Static & $105(50.5)$ & $103(49.5)$ & \multirow[t]{2}{*}{0.153} \\
\hline Kinetic & $8(34.8)$ & $15(65.2)$ & \\
\hline \multicolumn{4}{|l|}{ Ever used corsets } \\
\hline No & $103(51)$ & 99 (49) & \multirow[t]{2}{*}{0.096} \\
\hline Yes & $10(34.5)$ & $19(65.5)$ & \\
\hline \multicolumn{4}{|l|}{ Engage in physical exercise } \\
\hline No & $71(43.1)$ & $94(56.9)$ & \multirow[t]{3}{*}{$0.006^{*}$} \\
\hline Occasionally & $20(55.6)$ & $16(44.4)$ & \\
\hline Yes & $22(73.3)$ & $8(26.7)$ & \\
\hline \multicolumn{4}{|l|}{ Have diabetes } \\
\hline No & $103(51)$ & $109(49)$ & \multirow[t]{2}{*}{0.735} \\
\hline Yes & $10(52.6)$ & $9(47.4)$ & \\
\hline \multicolumn{4}{|l|}{ Have high blood pressure } \\
\hline No & $101(53.7)$ & $87(46.3)$ & \multirow[t]{2}{*}{$0.002 *$} \\
\hline Yes & $12(28)$ & $31(72)$ & \\
\hline \multicolumn{4}{|l|}{$\begin{array}{l}\text { Had major contusion with prolonged } \\
\text { healing }\end{array}$} \\
\hline No & $107(51.4)$ & $101(48.6)$ & \multirow[t]{2}{*}{$0.021^{*}$} \\
\hline Yes & $6(26.1)$ & $17(73.9)$ & \\
\hline \multicolumn{4}{|l|}{ Had fracture(s) in lower limb(s) } \\
\hline No & $104(52.5)$ & $94(47.5)$ & \multirow[t]{2}{*}{$0.007 *$} \\
\hline Yes & $9(27.3)$ & $24(72.7)$ & \\
\hline \multicolumn{4}{|l|}{ Had deep venous thrombosis } \\
\hline No & $106(49.5)$ & $108(50.5)$ & \multirow[t]{2}{*}{0.507} \\
\hline Yes & $7(41.2)$ & $10(58.8)$ & \\
\hline $\begin{array}{l}\text { Duration of standing during the working } \\
\text { day (mean } \pm \text { SD) }\end{array}$ & $6.47 \pm 2.65$ & $7.72 \pm 2.54$ & ${ }^{\mathrm{a}} 0.000^{*}$ \\
\hline Exercise duration per day (mean \pm SD) & $34.40 \pm 23.41$ & $57.71 \pm 33.62$ & ${ }^{\mathrm{a}} 0.002 *$ \\
\hline No. of times per week (mean \pm SD) & $3.57 \pm 1.43$ & $2.88 \pm 1.94$ & ${ }^{\mathrm{a}} 0.101$ \\
\hline
\end{tabular}

$\left(^{a}\right)$ p-value from an independent samples t-test; all others are from chi-square test. $\left(^{*}\right)$ statistically significant at $\mathrm{P}<0.05$. 
Table (6): Logistic regression analysis identifying the independent predictors of the occurrence of varicose veins in the study participants.

\begin{tabular}{|l|l|l|l|l|l|}
\hline Variables & \multirow{2}{*}{ B } & Sig. & \multirow{2}{*}{ OR } & \multicolumn{2}{l|}{ 95\% C.I. for OR } \\
\cline { 5 - 6 } & & & & Lower & Upper \\
\hline Occupation & -0.153 & $.008^{*}$ & 0.858 & 0.767 & 0.960 \\
\hline Education & 0.054 & .666 & 1.055 & 0.826 & 1.349 \\
\hline Age & 0.001 & .934 & 1.001 & 0.968 & 1.036 \\
\hline Weight & -0.010 & .341 & 0.990 & .970 & 1.011 \\
\hline Standing duration during the working day & 0.117 & $.023^{*}$ & 1.124 & 1.017 & 1.242 \\
\hline Engage in physical exercise & -0.873 & $<0.001^{*}$ & 0.418 & 0.273 & 0.639 \\
\hline Family history of varicose veins & 1.287 & $<0.001^{*}$ & 3.623 & 2.035 & 6.449 \\
\hline
\end{tabular}

(*) Statistically significant at $\mathrm{P}<0.05$, (C.I.) Confidence interval 
العربى الملخص

\section{الدوالي: الانتثار وعوامل الخطر المرتبطة بها بين النساء في سن الإنجاب اللائي يحضرن وحدة الرعاية الصحية الأولية، القاهرة ، مصر}

ساهر جمال يحيي محمد علي، مها مجدى و هدان، دينا هانى أحمد، عماد الدين فريد أبر اهيم، ضياء مرزوق عبد الحمبد

الخلفية: دوالي الأوردة شائعة جداً وتؤثر على الأفراد من جميع الإعمار؛ ومع ذلك، للأسف، المسببات المرضية لها مفهومة جزئيا. و هناك ندرة في الدر اسات التي أجريت في مصر للتحقيق في مدى انتشار ها وعو امل الخطر المرتبطة بها، لا سيما بين النساء في سن الإنجاب. الأهداف: أجريت هذه الدراسة لقياس مدى انتشار وتحديد عوامل الخطر المرتبطة بتوسع الأوردة بين النساء في سن الإنجاب (15-55 عاماً) الذين يترددون علي مركز الرعاية الصحية الأولية في القاهرة. المنهجية و طرق البحث: أجريت دراسة مقطعية علي231 من النساء المترددات على مركز النهضة في منطقة السلام الطبية في القاهرة، تم اختيار هن بواسطة تقنية أخذ العينات العشوائية المنتظمة. تم جمع البيانات باستخدام إستبيان المقابلة والفحص السريري. النتائج: أظهرت الدراسة أنه من بين 231 امر أة في سن الإنجاب (15-55 سنة) اللائي يحضرن مركز للرعاية الصحية الأولية في القاهرة ، (51.1 \%) كان لديهن الدوالي ، و أهم عو امل الخطر المرتبطة به كانت العمر (35.84 ـ 9.14 سنة) ، الوزن (78.13 ـ 13.62 كجم) ، ومدة الوقوف خلال يوم عمل (7.72 7.54 يومًا) ، وارتفاع ضغط الدم (72\%) ، ونقص النشاط البدني (56.9٪) ، وتاريخ عائلي للدو الي

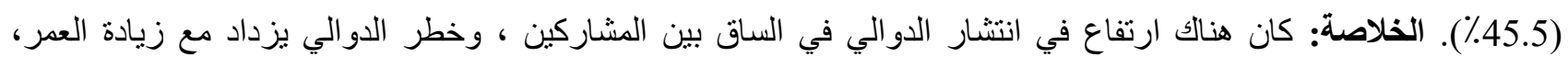
و الوقوف لفترات طويلة ، وارتفاع ضغط الدم ، وجود تاريخ عائلي من الدوالي و عدم ممارسة التمارين الرياضية بانتظام. التوصيات: ينبغي أن تهدف بر امج التثقف الصحي إلى التحكم في عوامل الخطر المسببة للدو الي التي يمكن الوقاية منها، كما يجب تعزيز الفحص للنساء ذوات تاريخ عائلي من الدوالي. 